\title{
Beyond an Emergency Declaration: Tribal Governments and the Opioid Crisis
}

\author{
Stacy L. Leeds*
}

The opioid crisis within the United States is often characterized as primarily impacting mainstream America, particularly suburban and rural white populations ${ }^{1}$ with predictive social and economic determinants. The epidemic is much more expansive than the original and reinforced popular narratives suggest. Between 2016 and 2017, American Indians and Alaska Natives (AI/AN) experienced the highest percentage rate increase in opioid prescription deaths and the second highest increase in overall opioid-related deaths. ${ }^{2}$

The opioid crisis has proven particularly disruptive to Indigenous Nations, and tribal governments have consequently engaged in many different strategies to bring relief to their communities, ${ }^{3}$ including

* Dean Emeritus, Professor of Law and Vice Chancellor for Economic Development at the University of Arkansas. Former Justice, Cherokee Nation Supreme Court. Wado to research assistant Hunter Dodson. This Article flows from and is devoted to the multi-year work of the attorneys in the Cherokee Nation Office of the Attorney General. Led by Attorney General Todd Hembree, Deputy Attorney General Chrissi Nimmo, and Assistant Attorney General John Young, the opioid litigations were also supported by the work of Cherokee Nation attorneys Alayna Farris, Paiten Taylor Qualls, and Chad Harsha. Additional leadership and contributions were provided by attorney Nikki BakerLimore serving as Director of Cherokee Nation Indian Child Welfare and attorney Sara Hill, now serving as Secretary of Natural Resources for the Cherokee Nation.

1. Mark Moran, How the Opioid Addiction Crisis Was Rendered 'White,' PsYCHIATRIC NEWS (Apr. 27, 2018), https://psychnews.psychiatryonline.org/doi/10.1176/appi.pn.2018.5a14 [https:// perma.cc/4K7Z-VG4P].

2. Ctrs. for Disease Control \& Prevention, Drug and Opioid-Involved Overdose Deaths-United States, 2013-2017, 67 Morbidity \& Mortality Weekly Report 1419, tbl.1 (Jan. 4, 2019), https://www.cdc.gov/mmwr/volumes $/ 67 / \mathrm{wr} / \mathrm{pdfs} / \mathrm{mm} 675152 \mathrm{e} 1-\mathrm{H} . \mathrm{pdf} \quad$ [https://perma.cc/ BMV7-9HDA]. There is a high likelihood that the harm to native communities is even greater than reported due to undercounting of Indigenous populations in state mortality statistics. See CTRS. FOR Disease Control \& Prevention, Drug, Opioid-Involved, and Heroin-Involved Overdose Deaths Among American Indians and Alaska Natives-Washington, 1999-2015, 67 Morbidity \& Mortality Weekly Report 1384 (Dec. 21, 2018), https://www.cdc.gov/mmwr/volumes/67/wr/mm6750a2. htm?s_cid=mm6750a2_w\&c_cid=journal_search_promotion_2018 [https://perma.cc/DXP8-JNQG] ("During 2013-2015, total drug and opioid-involved overdose mortality rates for AI/AN were 2.7 times higher than those of whites in [the state of] Washington. Misclassification of AI/AN race in death certificates underestimated Washington AI/AN overdose mortality by approximately $40 \%$."). See also infra note 4.

3. See generally Nicholet Deschine Parkhurst et al., The Opioid EPidemic IN Indian Country: What Tribal Leaders in ARIZONA NeEd to KnOw (2018), http://itcaonline.com/wp- 
litigation to recover mounting financial costs while the devastating impact continues to grow. In less than a twenty-year period, AI/AN have experienced a fivefold increase in deaths by drug overdose. ${ }^{4}$ The data is startling as it relates to the health prospects of the next generation. The projected nonmedical opioid use rate for $\mathrm{AI} / \mathrm{AN}$ youth is twice the estimated rate for white youths. ${ }^{5}$

Where relatively small populations are at issue within Indian country, ${ }^{6}$ the crisis produces an even more pronounced sense of urgency. ${ }^{7}$ The Mashpee Wampanoag Tribe, with a total population of approximately $2600,{ }^{8}$ issued a declaration of a public health state of emergency in $2016 .{ }^{9}$ The tribe's governmental declaration was issued after eleven opioidrelated deaths occurred in a little over one year. ${ }^{10}$ By comparison, if the surrounding state of Massachusetts were to experience the same single year impact, over 29,000 fatalities would result. ${ }^{11}$

content/uploads/2018/10/ITCA-TEC-Opioid-Report-2018.pdf [https://perma.cc/WJ6L-U7Y2]; Steve Dubb, American Indian Nations Respond to Opioid Epidemic in Their Communities, NONPROFIT Q. (Oct. 31, 2017), https://nonprofitquarterly.org/2017/10/31/american-indian-nations-respond-opioidepidemic-communities/ [https://perma.cc/UQE2-AHST].

4. Opioids in Indian Country: Beyond the Crisis to Healing the Community, Hearing Before the S. Comm. on Indian Affairs, 115th Cong. 15 (Mar. 14, 2018) (statement of Rear Admiral Michael Toedt, Chief Medical Officer of the Indian Health Service).

5. Addressing the Opioid Epidemic in American Indian and Alaska Native Communities, NAT'L INDIAN HEALTH BD., https://www.nihb.org/docs/09182017/Opioids\%20One\%20pager.PDF [https://perma.cc/CA8A-DYXD] (last visited Apr. 23, 2019).

6. "Indian country" is a legal term of art defined by Congress as a jurisdictional marker. This includes lands within reservation boundaries but is also broader than that territorial-based descriptor. 18 U.S.C. $\S 1151$ (2012).

7. This is true for the 8000 -citizen Seneca Nation.

Having survived numerous wars, famine, disease epidemics, the violent breakup of their territories and the consequent legal struggle to achieve sovereignty, the tribe now face[s] an existential crisis - one that ha[s] been brewing in the shadows long before anyone grasped its impact or could organize a response. No longer a discrete series of isolated incidences, opioid addiction had taken on a genuine sense of urgency.

Suzette Brewer, Tribes Lead the Battle to Combat a National Opioid Crisis, High CounTRY News (May 9, 2018), https://www.hcn.org/articles/tribal-affairs-tribes-lead-the-battle-to-combat-a-nationalopioid-crisis [https://perma.cc/7L5Q-BS5T].

8. MASHPEE WAMPANOAG TRIBE, https://mashpeewampanoagtribe-nsn.gov/ [https://perma .cc/DU2M-K46S] (last visited Mar. 7, 2019).

9. Sam Houghton, Mashpee Wampanoag Tribe Confronts Opioid Crisis, MASHPEE ENTERPRISE (July 21, 2016), https://www.capenews.net/mashpee/news/mashpee-wampanoag-tribeconfronts-opioid-crisis/article_b5f1d479-1564-5e0e-a043-c565621a145d.html [https://perma.cc/ CA7K-E5EV].

10. Id.

11. Massachusetts had an estimated population of 6.9 million in 2018. QuickFacts Massachusetts, U.S. CENSUS BUREAU, https://www.census.gov/quickfacts/fact/table/ma [https:// perma.cc/ZGF9-5BEZ] (last visited Mar. 7, 2019). 
The year after the Mashpee Wampanoag Tribe declared an emergency, the United States declared a public health emergency for the mobilization of federal administrative agencies and resources to curb the escalating opioid crisis. ${ }^{12}$ By that time, several tribal governments had already exercised sovereignty by issuing governmental emergency declarations ${ }^{13}$ including the Red Lake Band of Chippewa Indians, ${ }^{14}$ Leech Lake Band of Ojibwe, White Earth Nation, ${ }^{15}$ and Bad River Chippewa. ${ }^{16}$

\section{THE BIG PICTURE}

Tribal communities want what all communities want - the ability to prevent and respond to public health, welfare and safety crises in their own communities. Like states and local municipalities, tribes are often forced to rely on federal emergency management resources. ${ }^{17}$

Tribal governments want what all governments want - the ability to hold private parties accountable for conduct connected to a public health, welfare and safety crises. Like other governments, tribal would expect that local forums, with local judges and jurors, would be the appropriate venue for such disputes.

This Article focuses on the on-going Cherokee Nation opioid litigation as a case study. The Article highlights the political and legal strategies taken by the Cherokee Nation and other tribal governments as they seek to address the opioid crisis and explores the unique challenges and insights of tribes as they seek to implement strategies during this, and future, public

12. Memorandum on Combatting the National Drug Demand and Opioid Crisis, 2017 DAILY COMP. PRES. DoC. 788, at 2 (Oct. 26, 2017).

13. The Stafford Act allows access to federal resources; tribes may ask the President to declare a major disaster, or, alternatively, the state may ask for a presidential declaration on the tribe's behalf. 42 U.S.C. $\$ 5170$ (2012 \& Supp. V 2017). The 2013 amendments provide for tribes to obtain treatment as states. Pub. L. No. 113-2, 127 Stat. 4, 47-49 (2013).

14. Mary Lynn Smith, Red Lake Indian Reservation Declares Public Health Emergency Over Drug Epidemic, STAR TRIBUNE (July 26, 2017, 5:03 AM), http://www.startribune.com/red-lakeindian-reservation-declares-public-health-emergency-over-drug-epidemic/436633673/ [https://perma .cc/2D47-A2LZ].

15. Lawrence O. Gostin, James G. Hodge Jr., \& Sarah A. Noe, Reframing the Opioid Epidemic as a National Emergency, 318 J. AM. MED. ASS'N 1539, 1539 (2017).

16. BAD RIVER BAND OF LAKE SUPERIOR CHIPPEWAS, RES. NO. 11-1-17-914, RESOlUTION FOR DECLARATION OF a STATE OF EMERGENCY With RESPECT to PRESCRIPTION OPIATE MEDICATION AND ILLEGAL DRUG USE (Nov. 1. 2017), https://www.indianz.com/News/2017/11/08/badriverstateof emergency.pdf [https://perma.cc/78TY-KR7M].

17. A tribal set-aside of $\$ 50$ million was made by the Substance Abuse and Mental Health Services Administration (SAMHSA) through its Tribal Opioid Response Grant. See HHS Awards \$50 Million to Assist American Indian and Alaska Native Tribal Efforts Combating the Opioid Overdose Epidemic, U.S. DeP'T Health \& Hum. SERvs. (Sept. 26, 2018), https://www.hhs.gov/ about/news/2018/09/26/hhs-awards-50-million-assist-american-indian-and-alaska-native-tribalefforts-combating-opioid-overdose-epidemic.html [https://perma.cc/C5BE-K43M]. 
health crises.

As a starting point, it is important to note that tribes often simultaneously function in three otherwise distinct categories: first, as a sovereign government exercising jurisdiction to provide for public health, welfare, and safety; second, as an administrator of a comprehensive health care system; and finally, as the owner of business entities charged with revenue generation to fund the first two categories.

The comprehensive nature of a tribe's involvement and interaction with a community, which can include acting as government service provider, law enforcement, hospital administrator, self-insurer, and employer and business entity, places tribal governments in a vantage point unique among sovereigns. Tribal governments possess rich data to provide a more comprehensive understanding of the magnitude of the harm in a public health crisis. Given externally imposed limitations, tribes and tribal institutions are also particularly vulnerable and challenged in pursuit of political and legal remedies.

\section{A. Tribes as Governments}

As sovereigns, tribal governments carry out their obligation to tribal citizens and others within their jurisdiction, to provide basic services for health, welfare, and safety. Tribes generally provide for basic infrastructure and services and for the enforcement of rights and benefits through the exercise of civil and criminal jurisdiction. ${ }^{18}$ Tribes routinely carry out the same governmental functions as state and local governments, with the norm including law enforcement and judicial systems, tax commissions, environmental protection agencies, regulation of commerce, land use planning, and first responders.

Tribal governmental authority is presumed where the tribe governs tribal citizens. When tribal governmental powers extend to non-citizens, federal courts are increasingly unwilling to recognize tribal authority, absent an elevated showing that the non-citizen consented to tribal jurisdiction or conduct by the non-citizen that imperils the tribe's existence. ${ }^{19}$ Even when dangerous non-citizen conduct occurs on tribal

18. AngeliQue EagleWoman \& Stacy Leeds, Mastering American Indian LaW 39-69 (2013).

19. See, e.g., Nevada v. Hicks, 533 U.S. 353, 364-65 (2001) (holding tribes lack authority to regulate state officers serving process to residents who commit off-reservation crimes); Strate v. A-1 Contractors, 520 U.S. 438 (1997) (holding tribal courts lack jurisdiction to hear tort claims between non-members when the tortious conduct occurred on a federal highway built on a federal right-of-way crossing reservation land); Montana v. United States, 450 U.S. 544, 564-66 (1981) (tribes cannot regulate non-member hunting and fishing conducted on land located on a reservation but owned as fee 
lands, the recognized power of tribes to regulate or adjudicate such conduct has been increasingly limited.

Tribes face many challenges when it comes to their exercise of selfgovernance. Most notably, federal law does not recognize the tribe's ability to exercise full criminal jurisdiction. ${ }^{20}$ When a government is trying to respond to public health crises rooted in illegal drug distribution but lacks the authority to criminally prohibit and prosecute the conduct of all actors within their territorial jurisdiction, the fallback lies in fashioning other remedies rooted in the exercise of either civil jurisdiction or political diplomacy. Tribes are often forced to rely on state or federal governments.

Tribes, nonetheless, are often the only sovereign taking on the practical responsibility to provide for health, welfare, and safety within their jurisdictions. Although there are numerous circumstances when tribal relations with state and federal officers are strong and crossjurisdictional partnerships are effective, tribes often find themselves in conflict with states over resource allocations and disagreements over the scope of tribal sovereignty and decision-making. ${ }^{21}$

\section{B. Tribes as Administrators of Comprehensive Health Care Systems}

Most tribes oversee at least a portion of health care delivery in their communities and sixty percent of tribes run their own health care system, ${ }^{22}$ which can include clinics, hospitals, community health, behavioral health, and elder care. The Cherokee Nation's comprehensive health care system includes oversight and direct operation of eight health centers and a large hospital, ${ }^{23}$ with plans to open the first tribally-affiliated medical school in $2020 .^{24}$ The affiliated medical school will be located in the Cherokee

simple by non-members).

20. See Oliphant v. Suquamish Indian Tribe, 435 U.S. 191, 195 (1978) (barring categorically tribal criminal prosecution of non-Indians); but see Violence Against Women Reauthorization Act of 2013, § 904, Pub. L. No. 113-4, 127 Stat. 54, 120-23 (codified at 25 U.S.C. $§ 1304$ (Supp. V 2017)) (recognizing limited criminal jurisdiction over non-Indian domestic violence perpetrators in narrow contexts).

21. States and tribes often conflict over regulatory jurisdiction in matters of taxation, environmental controls, hunting and fishing and natural resources.

22. Jessica Bylander, Designing a Health System That Works for the Tribe, 36 HEALTH AFF. 592, 593 (2017), https:/www.healthaffairs.org/doi/pdf/10.1377/hlthaff.2017.0259 [https://perma.cc/ C4GB-94DN].

23. About Health Services, CHEROKEE NATION, https://www.cherokee.org/Services/Health/ About-Health-Services [https://perma.cc/9873-G9UL] (last visited Apr. 22, 2019).

24. Nation's First Tribally Affiliated College of Medicine Established Between Cherokee Nation and Oklahoma State University Center for Health Sciences, OKLA. ST. U. (Oct. 31, 2018), https://news.okstate.edu/articles/health-sciences/2018/first-tribally-affiliated-college-of-medicineestablished.html [https://perma.cc/U5ZU-76MU]. 
Nation's capital city, Tahlequah, Oklahoma, and will be established, in part, to address the physician-shortage crisis in rural Oklahoma and within tribal jurisdiction. ${ }^{25}$ Nationally, over 18,000 students graduated from medical school in 2015, but less than twenty were Indigenous. ${ }^{26}$

The federal government operates the Indian Health Service (IHS), an agency within the Department of Health and Human Services, to provide federal health services to members and citizens of federally-recognized tribes. ${ }^{27}$ Many tribes, however, contract with IHS to deliver these services locally, in combination with tribally-funded health care programs. Like the Veteran's Administration, it is a closed system serving a specific population based on the federal government's unique relationship with and responsibility to tribal governments. ${ }^{28}$

By participating in the Tribal Self-Governance Program, tribes can contract with the IHS to administer specific programs or services that IHS would otherwise provide, or a tribe can assume control over the entire health care program. ${ }^{29}$ When a tribe administers the local health care system, the tribe, while also functioning as a government exercising control over other social services, gets a unique and wholistic lens on the opioid and other public health care crises in the local community. Some patients will exclusively receive medical services from IHS or tribal facilities over the course of their lifetimes. In the Cherokee Nation, 58\% of the workforce is employed by Cherokee Health Systems. ${ }^{30}$

\section{Tribes as Business Entities}

Tribes engage in economic enterprises both within and beyond their territorial jurisdictions, whether as tribally-owned business entities and corporations, or instrumentalities of the tribal government. The revenues from such commercial activities are deployed to fund sovereign functions, including education and health care, and better situate tribes to be self-

\footnotetext{
25. Id.

26. Anh Gray, Where are all the Native Doctors?, Ass'N AM. INDIAN PHYSICIANS (Oct. 31, 2016), https://www.aaip.org/media/news/m.blog/76/where-are-all-the-native-doctors [https://perma. cc/K4TY-U736].

27. Agency Overview, INDIAN HEALTH SERV., https://www.ihs.gov/aboutihs/overview/ [https://perma.cc/ALG3-AVTY] (last visited Apr. 22, 2019).

28. See Quick Look, INDIAN HEALTH SERV., https://www.ihs.gov/newsroom/factsheets/ quicklook/ [https://perma.cc/93UB-FLBE] (last visited Apr. 22, 2019).

29. Office of Tribal Self-Governance, About Us, InDIAN Health SERV., https://www.ihs.gov/selfgovernance/aboutus/ [https://perma.cc/58GN-U79M] (last visited Apr. 22, 2019).

30. About Health Services, supra note 23.
} 
sufficient and less reliant on sources of federal funding. ${ }^{31}$ Unlike federal and state counterparts, tribal governments are often barred from generating tax revenue to fund tribal government programs, either because of legal obstacles to the exercise of tribal tax powers or by the practical realities of tax collection. Dual taxation with state governments have the practical effect of ousting tribal tax or, at the least, lowering the tribal tax revenue stream from a practical perspective. ${ }^{32}$

As business owners, loss of economic power from the opioid crisis is magnified. Not only does the crisis negatively impact the profitability of the business by increased health benefits costs, but tribal businesses, like other businesses in the United States, also see a diminished labor force. Finally, when tribal business profitability declines, government revenue declines, and there is a direct impact on the ability of the government to fund education and public health programs in an inter-related fashion that is more pronounced in tribal communities.

In many communities, tribes are the largest employers in the regional economy. Tribes are often relied upon as the engines of economic development. The U.S. Department of Labor recently awarded the Cherokee Nation a grant from its Dislocated Worker Fund "to provide jobs and employment services to those impacted by the health and economic effects of opioid use, addiction and overdose." 33 The funding was made available after the national declaration of emergency for the opioid crisis. ${ }^{34}$ The tribes serve both tribal citizens and noncitizens within their jurisdiction and frequently contribute to local state projects by profitsharing, government revenue compacts, and by other contributions.

\section{THE CHEROKEE NATION LAWSUITS}

Since 2017, the Cherokee Nation has been involved in a multi-front litigation involving tribal and state county courts in the Cherokee Nation and Oklahoma, as well as three federal district courts in Oklahoma and

31. See Mark J. Cowan, Double Taxation in Indian Country: Unpacking the Problem and Analyzing the Role of the Federal Government in Protecting Tribal Governmental Revenues, 2 PITT. TAX REV. 93, 95 (2005).

32. Id.

33. Cherokee Nation Awarded up to \$6M Dislocated Worker Grant, NATIVE Bus. MAG. (Feb. 17, 2019), https://www.nativebusinessmag.com/cherokee-nation-awarded-up-to-6m-dislocatedworker-grant/ [https://perma.cc/2G3G-HE7H]; see also Press Release, U.S. Dep't of Labor, U.S. Department of Labor Provides National Health Emergency Dislocated Worker Grant to Combat Opioid Crisis in the Cherokee Nation (Feb. 11, 2019), https://www.dol.gov/newsroom/ releases/eta/eta20190211 [https://perma.cc/AJ2F-8745].

34. Press Release, supra note 33. 
Ohio. ${ }^{35}$ The Cherokee Nation's goal is to proceed to a jury trial within the Cherokee Nation political and territorial boundaries, whether that be in tribal or state court. At present, the Cherokee Nation has been denied a local forum and instead is proceeding as a last resort in a federal multidistrict litigation (MDL) in a federal court in Ohio. ${ }^{36}$ There is no modern Indian country in Ohio. ${ }^{37}$ The self-reported native population of the state, which includes all indigenous people of North and South America, is $0.3 \%{ }^{38}$ A total of 709 Cherokee Nation citizens reside in Ohio. ${ }^{39}$ In contrast, over 175,000 of the total 335,000 Cherokee Nation citizens live where the case was originally filed. ${ }^{40}$

\section{A. The Tribal Court Case}

In April 2017, the Cherokee Nation initiated a lawsuit in the Cherokee Nation District Court against opioid pharmaceutical distributors and retailers, ${ }^{41}$ becoming the first plaintiff to file an action of this nature in a tribal court. ${ }^{42}$ The Cherokee Nation District Court is a court of general jurisdiction as defined by Cherokee law. ${ }^{43}$ The Cherokee Nation encompasses all of northeastern Oklahoma, including all or parts of

35. In re Nat'l Prescription Opiate Litig., 327 F. Supp. 3d 1064, 1068 (N.D. Ohio 2018) (describing the procedural history).

36. See id. (denying the Cherokee Nation's motion to remand the suit back to the Eastern District of Oklahoma).

37. Federal and State Recognized Tribes, NAT'L CONF. St. LegisLatures, http://www.ncsl.org/research/state-tribal-institute/list-of-federal-and-state-recognized-tribes.aspx [https://perma.cc/JY2P-W634] (last visited Mar. 13, 2019) (noting no recognized tribes are located in Ohio).

38. QuickFacts Ohio, U.S. CENSUS BUREAU, https://www.census.gov/quickfacts/oh [https://perma.cc/23NE-SLZE] (last visited Mar. 5, 2019). The broad category as defined in Ohio census data includes all persons having "origins in any of the original peoples of North and South America (including Central America) and who maintains tribal affiliation or community attachment. This category includes people who indicate their race as 'American Indian or Alaska Native' or report entries such as Navajo, Blackfeet, Inupiat, Yup'ik, or Central American Indian groups or South American Indian groups." Id.

39. E-mail from Cherokee Nation Registration Department to author (Mar. 5, 2019, 10:12 AM, CST) (on file with author).

40. Petition at 8, Cherokee Nation v. McKesson Corp., No. CV-2017-203 (Cherokee Nation D. Ct. Apr. 20, 2017), No. 1.

41. Defendants are six corporations: (1) CVS, (2) Walgreens, (3) Walmart (1-3 are pharmacies), (4) McKesson Corp., (5) Cardinal Health, and (6) AmerisourceBergen (3-6 are distributors). See id. at 4-6.

42. Lenzy Krehbiel-Burton, Judge Deals Setback to Cherokee Nation Lawsuit over Opioids, REUTERS (Jan. 10, 2018), https://www.reuters.com/article/us-cherokee-opioids/judge-deals-setbackto-cherokee-nation-lawsuit-over-opioids-idUSKBN1EZ2J6 [https://perma.cc/5QG5-YWAE] (noting the Cherokee Nation was the first major tribe to sue in tribal court).

43. CherokeE NATION CONST. art. VIII, § 6; 20 C.N.C.A. § 24 (2015). 
fourteen counties. ${ }^{44}$

The complaint alleged Cherokee common law claims and Cherokee statutory claims under the Cherokee Nation Unfair and Deceptive Trade Practices Act. ${ }^{45}$ The damages sought were tied to the industry's alleged role in the opioid epidemic inside the Cherokee Nation, including failure to exercise care to avoid diversion. ${ }^{46}$ Among the claims advanced by the Cherokee Nation was that, in 2015, 845 million milligrams of opioids were dispensed within the tribe's fourteen county jurisdiction, which amounts to 703 milligrams (or between thirty-five to seventy opioid pills assuming doses of ten to twenty milligrams per pill) for every Cherokee Nation citizen within the tribe's territory. ${ }^{47}$

The diversion argument is unique to the Cherokee Nation because its government operates a comprehensive health care system that took steps to limit opioid prescriptions. ${ }^{48}$ Although some opioids were distributed at the Cherokee Nation health facilities, the Cherokee Nation took aggressive steps to eliminate the flow of opioids to its own patients, including limiting pharmaceutical sales representatives' access to physicians, monitoring the number of prescriptions, and categorically banning certain drugs from being prescribed. ${ }^{49}$ As early adopters of technology to combat diversion or misuse, the Cherokee Nation used prescription monitoring services before it was required in other jurisdictions, including the surrounding state of Oklahoma. ${ }^{50}$

The Cherokee Nation has taken precautions at its own dispensing facilities to prevent prescription opioid abuse. These precautions include not prescribing and/or dispensing hydrocodone. ${ }^{51}$ Despite these safeguards, diversion of the Defendants' drugs has resulted in a Cherokee citizen opioid addiction that exceeds the U.S. national average. ${ }^{52}$

With close monitoring of the data, including data obtained from state databases, the Cherokee Nation attributed the rise in opioid deaths and addiction, including addicted infants born at Cherokee health care

44. These counties are Adair, Cherokee, Delaware, Mayes, McIntosh, Muskogee, Nowata, Washington, Tulsa, Ottawa, Rogers, Sequoyah, Wagoner and Craig counties. See Fourteen County at a Glance, CHEROKEE NATION, https://cherokee.org/Portals/cherokeeorg/Documents/3308014 _County_At_A_Glance.pdf [https://perma.cc/4BG9-WF3Y] (last visited Apr. 22, 2019).

45. Petition at 41-50, Cherokee Nation, No. CV-2017-203.

46. Id. at 42 .

47. Id. at 18 .

48. About Health Services, supra note 23 (noting the services the Nation provides).

49. Petition at 17, Cherokee Nation, No. CV-2017-203.

50. Id.

51. Id.

52. Id. 
facilities, to outside sources. The Cherokee Nation had seen an uptick in opioid related deaths, family law cases, crime, and employee absenteeism. In the Cherokee Nation social welfare system, opioids were a factor in forty-one percent of the open caseload. ${ }^{53}$ The Cherokee Nation also claimed that between 2003 and 2014 there were over 350 opioid deaths within the Cherokee Nation. ${ }^{54}$ Deaths from opioid-related overdoses more than doubled within the Cherokee Nation between 2003 and 2014. ${ }^{55}$ For adults within the Cherokee Nation, overdose deaths exceeded the number of deaths due to automobile accidents in 2014. ${ }^{56}$

The Cherokee Nation theorized that individuals were either obtaining opioids from an illicit market made possible by diversion or obtaining opioids from retail pharmacies that were not exercising proper care. In both instances, the Cherokee Nation alleged the distributors knew or should have known that the number of pills finding their way into the jurisdiction far exceeded the appropriate medical demand. ${ }^{57}$

The Cherokee Nation drew from statistics which ranked Oklahoma as first in the nation for the nonmedical use of prescription opioids, which included resident Cherokee Nation citizens. ${ }^{58}$ Oklahoma is home to thirtysix federally recognized tribes. ${ }^{59}$

Following the Cherokee Nation filings, several other tribes have filed lawsuits in state and federal courts alleging that the pharmaceutical industry uniquely harmed tribal communities. ${ }^{60}$

States with high native populations tell a similar story. In South Dakota, where natives make up nine percent of the state's population, native patients constituted nearly thirty percent of the total patients being treated for opioid-related medical care and addiction. ${ }^{61}$ Similarly, all the

53. Brewer, supra note 7; Kristi Eaton, Opioid Epidemic Threatens the Children-and Futureof Cherokee Nation, THE LILY (May 3, 2019), https://www.thelily.com/opioid-epidemic-threatensthe-children-and-future-of-cherokee-nation/ [https://perma.cc/A34T-K2J3].

54. Petition at 18, Cherokee Nation, No. CV-2017-203.

55. Id.

56. Id.

57. Id. at $30-33,36-38$.

58. Id. at 17 .

59. Federal and State Recognized Tribes, supra note 37 (noting Oklahoma contains thirty-eight recognized tribes).

60. See, e.g., Complaint, Navajo Nation v. Purdue Pharma L.P., No. 18-338 (D.N.M. Apr. 11, 2018); Complaint, Muscogee (Creek) Nation v. Purdue Pharma L.P., No. 18-cv-00180-JHP-JFJ (N.D. Okla. Apr. 3, 2018); Complaint, Flandreau Santee Sioux Tribe v. Purdue Pharma L.P., No. 18-4003 (D.S.D. Jan. 8, 2018).

61. Amy Dalrymple, Native American Tribes File Federal Lawsuit Against Opioid Industry, BISMARCK TRIB. (Jan. 8, 2018), https://bismarcktribune.com/news/state-and-regional/nativeamerican-tribes-file-federal-lawsuit-against-opioid-industry/article_a559559a-dfd7-5b01-893f-

78d0aef2f2fe.html [https://perma.cc/643D-FG76]. 
tribes have been denied local forums and have been required to pursue their claims in the Ohio multi-district litigation.

\section{B. The Federal Court Challenge to Tribal Jurisdiction}

The Cherokee Nation case did not advance to trial in the Cherokee Nation District Court. Shortly after the tribal court case was initiated, the defendants sought federal court relief, objecting to the jurisdiction of the Cherokee Nation District Court. ${ }^{62}$ The parties jointly requested a stay of tribal court proceedings pending resolution of the federal action. ${ }^{63}$ Following such action, as described below, the Cherokee Nation voluntarily dismissed the tribal court case in January 2018 following a federal court injunction barring the tribal court from exercising jurisdiction over defendant companies. ${ }^{64}$

In McKesson Corp. v. Hembree, the District Court for the Northern District of Oklahoma ruled that the Cherokee Nation District Court lacked jurisdiction. ${ }^{65}$ Generally, the "sovereign powers of an Indian tribe do not extend to the activities of nonmembers of the tribe," subject to two exceptions: "a tribe may regulate ... the activities of nonmembers who enter consensual relationships with the tribe or its members;" and a tribe may "exercise civil authority over the conduct of" nonmembers whose conduct within its reservation "threatens or has some direct effect on the political integrity, the economic security, or the health or welfare of the tribe." 66

However, the court determined that under the Montana consensual relationship review, the commercial relationships alleged by the Cherokee Nation were inadequate. ${ }^{67}$ The court noted that the first Montana exception typically applied to "the taxation of business activities or transactions involving nonmembers" of a tribe, which were distinct from claims of nuisance, negligence, unjust enrichment and conspiracy. ${ }^{68}$ Furthermore, the court found no nexus between the tort injuries alleged by the Cherokee Nation and the Plaintiff pharmacies and distributors who had

62. See McKesson Corp. v. Hembree, No. 17-CV-323-TCK-FHM, 2018 WL 340042, at *2 (N.D. Okla. Jan. 9, 2018).

63. Joint Motion for Limited Stay of Proceedings, Cherokee Nation, No. CV-2017-203 (June 26, 2017), No. 16.

64. Order of Dismissal Without Prejudice, Cherokee Nation, No. CV-2017-203 (Jan. 22, 2018), No. 29.

65. McKesson Corp., 2018 WL 340042, at*1.

66. Id. at *3 (quoting Montana v. United States, 450 U.S. 544, 565-66 (1981)).

67. $\quad I d$. at $* 7$.

68. Id. 
no contractual relationship with the tribe and had not specifically sought out tribal members. ${ }^{69}$

Under the second Montana exception, the direct-effects review, the Cherokee Nation's allegation of harm was deemed to be distinct from that to which the exception applied. The exception, the court explained, "envisions situations where the conduct of the nonmember poses a direct threat to tribal sovereignty" or when the conduct is "catastrophic for tribal self-government." "70 conduct must "imperil[] the subsistence of the tribal community" and does not reach "beyond what is necessary to protect tribal self-government or to control internal relations." 71 The Cherokee Nation alleged that "70 to 80 percent of crimes that lead to convictions of [its] citizens are drug-related, including 'property crimes to get money to buy pills." 72 It also showed the "'staggering increase' in the number of Cherokee babies ... dependent on opioids at birth" that leads to more outplacements in the child welfare system "where they are raised without exposure to the tribe's language, history, traditions, and customs." 73 Nonetheless, the court held that "the Cherokee Nation's claims in this case "concern actions that threatened an individual tribal member"' but was not "catastrophic for tribal self-government." 74

\section{The State Cases}

Ten days after the federal dismissal, the Cherokee Nation filed the first of two lawsuits it would eventually file in the Oklahoma state court in Sequoyah County. The first case mirrored the tribal court case. ${ }^{75}$ The second case was initiated by the Cherokee Nation against a new defendant, Purdue Pharma, the first manufacturer from which the Cherokee Nation sought relief. ${ }^{76}$

Ultimately however, McKesson removed the case to federal court,

\footnotetext{
69. Id.

70. Id. at *8 (first quoting Philip Morris USA, Inc. v. King Mountain Tobacco Co., 569 F.3d 932, 943 (9th Cir. 2009); then quoting Plains Commerce Bank v. Long Family Land \& Cattle Co., 554 U.S. 316, $341(2008))$.

71. Id. at *7 (first quoting Crowe \& Dunlevy, P.C. v. Stidham, 640 F.3d 1140, 1153 (10th Cir. 2011); then quoting Strate v. A-1 Contractors, 520 U.S. 438, 459 (1997)).

72. Id.

73. Id.

74. Id. at *9 (first quoting Norton v. Ute Indian Tribe of the Uintah \& Ouray Reservation, 862 F.3d 1236, 1247 (10th Cir. 2017); then citing Plains Commerce Bank, 554 U.S. at 341).

75. See Cherokee Nation v. McKesson Corp., No. CJ-2018-00011 (Okla. D. Ct. Sequoyah Cty. Jan. 19, 2018).

76. Cherokee Nation v. Purdue Pharma L.P., No. CJ-2018-00086 (Okla. D. Ct. Sequoyah Cty. June 19, 2018).
} 
arguing that "McKesson is an entity acting under direction of federal officers and has been sued on claims that relate to its actions under color of federal office."77 Similarly, Purdue Pharma successfully removed the case against it to federal court. ${ }^{78}$ These two cases were later assigned to multidistrict litigation (MDL) in Ohio. ${ }^{79}$ The defendants were successful in ending the tribal court case and subsequently removing both state court cases to multidistrict litigation.

The original Sequoyah county petition filed on June 19, 2018, argues that sales have taken place in Oklahoma inside the county. ${ }^{80}$ In 2016, 14,000 Cherokees lived in Sequoyah County and the CN Health Center in Sequoyah County served 100,000 patient visits for medical care with 1,200 jobs supported. ${ }^{81}$ The Cherokee Nation gave $\$ 4$ million to Sequoyah county schools and $\$ 150$ million in local income. ${ }^{82}$

\section{THE Multi-District FEDERAL LitiGATION}

Four hundred and forty-eight federally recognized tribes are now involved as litigants or amici in the MDL. ${ }^{83}$ A separate trial track in the MDL for all federally recognized Indian tribes was approved on June 4, 2018 (567 tribes were federally recognized at the time of approval). ${ }^{84} \mathrm{~A}$ special master was assigned the task of "working with the Tribes to develop a Case Management Order and a separate MDL track." ${ }^{85}$ In addition to tribes, the MDL consists of government entities, including hospitals, third-party payors, and individuals. Of the 1150 cases filed,

77. Notice of Removal at 2, Cherokee Nation v. McKesson Corp., No. 6:18-CV-00056 (E.D. Okla. Feb. 26, 2018), ECF No. 2.

78. Notice of Removal, Cherokee Nation v. Purdue Pharma L.P., No. 6:18-CV-00236 (E.D. Okla. July 25, 2018), ECF No. 2.

79. Transfer Order, In re Nat'l Prescription Opiate Litig., No. 1:17-md-02804-DAP (J.P.M.L. Dec. 10, 2018) (transferring Cherokee Nation v. Purdue Pharma L.P.), ECF No. 1175; Transfer Order, id. (June 6, 2018) (transferring Cherokee Nation v. McKesson Corp.), ECF No. 559.

80. Petition at 6, Cherokee Nation v. Purdue Pharma L.P, No. CJ-2018-00086.

81. Original Petition at 7-8, Cherokee Nation v. McKesson Corp., No. CJ-2018-00011 (Okla. D. Ct. Sequoyah Cty. Jan. 19, 2018).

82. Id. at 8 .

83. Brief Amici Curiae of 448 Federally Recognized Tribes in Opposition to Defendants' Motions to Dismiss Tribal Claims at 1, In re Nat'1 Prescription Opiate Litig., No. 1:17-md-02804DAP (N.D. Ohio Oct. 5, 2018), ECF No. 1026.

84. Order re: Reassigning Workload, $i d$. (June 4, 2018), ECF No. 549. See also Separate Track Created in Opioid MDL for all 567 Indian Tribes in United States, 2018-4551 MEALEY's DAILY NEWS UPDATE 2 (June 6, 2018), https://www.lexislegalnews.com/articles/27316/separate-track-created-inopioid-mdl-for-all-567-indian-tribes-in-united-states.

85. Order re: Reassigning Workload, supra note 84. 
fifty-three of the filings are tribal initiated. ${ }^{86}$

The initial Transfer Order transferring individual actions to MDL status in the U.S. District Court for the Northern District of Ohio was issued in December 2017. ${ }^{87}$ The presiding Judge, the Honorable Dan Aaron Polster, is an experienced judge presiding over other past MDLs ${ }^{88}$ and other opiate cases. ${ }^{89}$

None of the individual actions initially transferred to MDL were tribal lawsuits, ${ }^{90}$ although at least one tribe had filed in a federal district court at that time. ${ }^{91}$ The Cherokee Nation had also filed an opioid lawsuit at that time in Cherokee Nation tribal court. ${ }^{92}$ There is no authority for federal removal from a tribal court. ${ }^{93}$

Two tribes have sought to have the MDL claims remanded to state court, the Cherokee Nation and the Lac Courte Oreilles Band of Lake Superior Chippewa Indians. ${ }^{94}$ Rather than filing in tribal court, the Lac Courte Oreilles Band of Lake Superior Chippewa Indians originally initiated a lawsuit in the state courts of Wisconsin. ${ }^{95}$

At the time that both tribal remand motions were denied, effectively making the MDL the exclusive venue for tribal claims, fifty-three of the cases in the MDL had been filed by tribes. ${ }^{96}$ Subsequently, numerous "tagalong" transfer orders have been issued, at least two of which have included one or more tribal opiate lawsuits. ${ }^{97}$

The most recent development in the MDL is a January 2019 issuance of a deadline for new Track One Cases and other scheduling matters. ${ }^{98}$ At

\footnotetext{
86. In re Nat'1 Prescription Opiate Litig., 327 F. Supp. 3d 1064, 1068 (N.D. Ohio 2018).

87. See In re Nat'l Prescription Opiate Litig., 290 F. Supp. 3d 1375 (J.P.M.L. 2017).

88. Id. at 1379 (noting Judge Polster's participation in In re Gadolinium Contrast Dyes Products Liability Litigation).

89. See id.

90. See id. at $1380-82$.

91. Complaint, St. Croix Chippewa Indians of Wisconsin v. McKesson Corp., No. 3:17-CV00914 (W.D. Wis. Dec. 6, 2017), ECF No. 1.

92. Petition, supra note 40.

93. 28 U.S.C. \$1441(a) is limited in scope to state court removals. See Gourneau v. Love, 915 F. Supp. 150, 152-53 (D.N.D. 1994) (finding $§ 1441$ (a) removal does not apply to cases brought in tribal court).

94. In re Nat'l Prescription Opiate Litig., 327 F. Supp. 3d 1064, 1067 (N.D. Ohio 2018). These motions were denied on September 4, 2018. Id. at 1079.

95. Id. at 1068 .

96. Id.

97. Transfer Order at sched. A, In re Nat'l Prescription Opiate Litig., No. 1:17-md-02804-DAP (J.P.M.L. Feb. 7, 2019), ECF No. 1345 (transferring seven cases to the MDL, including Choctaw Nation v. Purdue Pharma L.P., No. 6:18-00355 (E.D. Okla.), and Chickasaw Nation v. Purdue Pharma L.P., No. 6:18-00356 (E.D. Okla.)).

98. See Case Management Order No. 8 Setting New Deadlines for Track One Cases, In re Nat'1
} 
the date of this publication, the special masters had yet to issue scheduling orders with respect to the tribal track jurisdictions. ${ }^{99}$

Interestingly, the State of Oklahoma, which followed the Cherokee Nation by filing a similar lawsuit in its own courts, appears to be the first of the opioid cases heading for trial. ${ }^{100}$ Some commentators suggest that the outcome of the Oklahoma state court case could foreshadow that of the MDL. ${ }^{101}$ The Oklahoma state court trial is currently scheduled to begin on May 28, 2019. ${ }^{102}$ The federal court lacks jurisdiction over states attorneys general who bring state-based claims in state court. In contrast, all tribal cases have now been removed to federal court and transferred to MDL.

\section{CONCLUSION}

Although tribal nations have well-recognized self-governance in many areas, including land management, self-governance, taxation and domestic relations, a review of tribal court jurisdictional cases demonstrates how difficult it is for tribes to gain recognized authority to address public health crises, even over alleged injuries in mass tort claims. Despite tribal law and treaty provisions to the contrary, the federal courts have not recognized tribal courts as courts of general jurisdiction absent two increasingly narrow exceptions, which involve highly engaged consensual relationships and an elevated showing of impact on health and welfare that must rise to the level of imperiling a tribe's political existence. If the opioid crisis does not rise to the level of seriousness to invoke the tribe's jurisdiction or, in the alternative, the tribe's right to a local forum even in the surrounding state courts, it is hard to envision what would.

In the context of environmental regulations, Congress provided mechanisms for tribes to be treated as states. Congress also provided limited jurisdiction for tribal courts to exercise criminal jurisdiction over

Prescription Opiate Litig., No. 1:17-md-02804-DAP (N.D. Ohio Jan. 29, 2019), ECF No. 1306. The document sets various relevant dates, including deadlines for Plaintiffs' and Defendants' expert reports (March 25, 2019 and May 10, 2019, respectively), the final pretrial hearing (October 15, 2019), and date of trial (October 21, 2019). Id. at 1-2.

99. See Case Management Order No. 1 at 8, In re Nat'1 Prescription Opiate Litig., No. 1:17-md02804-DAP (N.D. Ohio Apr. 11, 2018), ECF No. 232 (requiring a conference by August 17, 2018 to establish a process and schedule for tribal cases).

100. Lenny Bernstein \& Katie Zezima, Oklahoma Could Provide First Test of Who Will Pay for the Opioid Crisis-and How Much, WASH. POST (Feb. 20, 2019), https://www.washington post.com/national/oklahoma-could-provide-first-test-of-who-will-pay-for-the-opioid-crisis - andhow-much/2019/02/19/c35ad366-3082-11e9-8ad3-9a5b113ecd3c_story.html?utm_term=.c300950 7e8b4 [https://perma.cc/P3V8-Q8KJ].

101. Id.

102. Id. 
non-Indians in domestic violence cases, provided the tribal courts possess certain threshold due process guarantees, many of which are already present as a practical consideration as a matter of tribal law and not in response to federal concerns. Similar considerations and legislative reform should follow as an outgrowth of the tribal experiences in seeking justice in combatting the opioid crisis. 